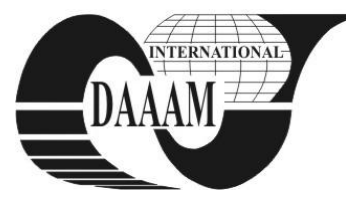

Annals of DAAAM for 2011 \& Proceedings of the 22nd International DAAAM Symposium, Volume 22, No. 1, ISSN 1726-9679 ISBN 978-3-901509-83-4, Editor B. Katalinic, Published by DAAAM International, Vienna, Austria, EU, 2011 Make Harmony between Technology and Nature, and Your Mind will Fly Free as a Bird

Annals \& Proceedings of DAAAM International 2011

\title{
EXPLORING THE ROLE PLAYED BY CHILDREN AND TWEENS IN ADVERTISING USING CONTENT ANALYSIS
}

\author{
COSOI, C[armen] M[aria]
}

\begin{abstract}
While children have always been one of the favorite symbols used in advertising throughout the years, this phenomenon is increasing constantly, as the marketing industry is focusing even more on young emerging segments such as children and tweens. The paper aims to explore this trendon the Romanian market, of advertising featuring more and more children and tweens in the attemp to increase likeability and emotional response from consumers along with identifying the product categories or services most likely to benefit from this type of commercials.
\end{abstract}

Key words: advertising, children, content analysis, tweens

\section{INTRODUCTION}

One of the golden rules of advertising says that children, animals and sex always sell, as it has been proved over and over again that the emotions or attraction driven by commercials featuring one of these elements appeal to a wide audience allowing for good exposure of the product advertised. Nevertheless, one should fairly know that these are not symbols that can be used anytime and in any conditions. With the rise of a fast growing segment "the new age consumer", the focus of the entire marketing industry is moving towards this direction, the younger segments of consumers are being put in the spot light more and more. Research conducted in the past years revealed that children and tweens make their debut as consumers from very early ages (Valkenburga \& Cantor, 2001) especially when it comes to product categories that are easily available to them and do not require a considerable investment, while at the same time are also fierce influencers for products which do not concern them whatsoever, such as the family car and the insurance plan for the entire household (McNeal, 1999). Having all this in mind, corroborated with the enormous emotional response triggered by featuring children in TV commercials, advertisers resort more and more to this technique by increasing the number of commercials featuring children and tweens.

\section{CHILDREN, TWEENS AND ADVERTISING}

Toddlers, children and tweens represent the main attractions in terms of TV commercials and because of the positive reaction triggered, it is highly important to measure the level of this phenomenon on the Romanian market. Although, the importance of the tweens and children segments is constantly growing, the Romanian market is still at an early stage compared to countries such as United States or United Kingdom where this phenomenon is taking everybody by storm.

Children and especially tweens nowadays represent a highly important segment for marketers due to three main reasons: they dispose of increasingly large amounts of money which qualify them as an important primary market, will grow and develop into mature consumers ensuring a loyal future market, they have started to develop brand loyalty at an early age, positive attitudes that will most likely last until adulthood for certain brands and last but not least, are powerful influencers for the household purchases in general.

At the same time, the marketing activities and especially advertising continues to expand in Romania, as constantly ways of improving the brand performance are sought after. Consequently, children/tweens find themselves casted in an heavily increasing number of commercials due to the characteristics described above, but also since the public's reaction in general is a very good one which helps cutting through the clutter and increase the attractiveness of the commercials. Although, it is easy to observe that this phenomenon of commercials featuring children and tweens is developing consistently, however the exact extent was not yet quantified, nor did the product categories more likely to resort to this technique.

Children and tweens being features in advertisings do not only influence the main decision makers, meaning parents, but also peak the curiosity and interest of their pears in the respective brand, creating awareness and most likely consideration. From now on, in case the product is suitable for the children and tween segment, the young viewer will process the information received through the ad and become persuaded to buy the product, or in case it is related to products or services not aimed at this target, will start play their role as influencers. Having all this in mind, quantifying and understanding the penetration rate of commercials featuring children and tweens along with analyzing their content represents an important aspect that will provide valuable information on how to better apply it, while at the same time build awareness among parents related to the size of this phenomenon so as to take decisions in the future in the best interest of their children.

Previous research focused mainly on providing information on the number of hours/minutes of commercials targeted at children and the ratio of air space filled by these ads during airing time that was addressed to this audience. Kotz \& Story, in a similar experiment conducted in 1994, quantify the number of commercials aired during Saturday morning children's programming so as to identify the number of advertisings for food items.

The approach used for this paper aims at providing a broader view, as the author will be focusing on analyzing the whole spectrum of TV programs, not only the shows addressed to children, covering both weekdays and weekends in order to identify the commercials featuring children, toddlers and tweens, quantify them and conduct a content analysis so as to reveal the product categories most appropriate for featuring children and tweens along with the elements with the highest penetration. The goal of this research is to see past the commercials addressing children and featuring children and tweens as actors and try and capture the extent of the phenomenon of them being distributed in ads exclusivelly due to their increasing influence over the family acquisitions. All these actions determine children and tweens to mature quickly as consumers due to increased exposure to marketing activities in general and commercials and materials featuring children 
their age, that make the materials more approachable and in the end more memorable.

\section{RESEARCH DESIGN}

The research technique applied was content analysis of commercials featuring children and tweens, ads aired by the number one TV station in Romania, Pro TV with a market share of $14,1 \%$ (ARMA-GFK Romania). During four days, comprising a mix of week days (Wednesday and Thursday) and weekends (Saturday and Sunday) in November 2010 all the programming aired by Pro TV between 8 am and $10 \mathrm{pm}$ (the hour interval most appropriate for this age segment) were recorded and stored on the computer by using a TV tuner, resulting in 56 hours of recording.

The information was gather by covering the following areas: day of ad broadcast, the hour interval when the commercial broadcast accrued, the ad duration, the product category or service, the brand and if the product was addressed to children or tweens.

\section{RESULTS}

Out of the 784 minutes of commercials recorder during the 4 days, $47 \%$ featured children or tweens, proving that indeed this segment can somehow associated with a gold mine for advertising, since keeps viewers in front of the TV and more interested in purchasing the product or service (see table 1 and 2).

\begin{tabular}{|c|c|c|}
\hline $\begin{array}{c}\text { Total number of } \\
\text { recorded minutes }\end{array}$ & $\begin{array}{c}\text { Total number of } \\
\text { commercials } \\
\text { minutes }\end{array}$ & $\begin{array}{c}\text { Number of } \\
\text { commercials } \\
\text { minutes featuring } \\
\text { children or tweens }\end{array}$ \\
\hline $3360 \mathrm{~min}$ & $784 \mathrm{~min}$ & $371 \mathrm{~min}$ \\
\hline
\end{tabular}

Tab. 1. The structure of the recorded minutes

\begin{tabular}{|c|c|c|c|}
\hline & $\begin{array}{c}\text { Recorded } \\
\text { commercials }\end{array}$ & $\begin{array}{c}\text { Commercials } \\
\text { featuring } \\
\text { children or } \\
\text { tweens }\end{array}$ & $\begin{array}{c}\text { Commercials } \\
\text { not featuring } \\
\text { children of } \\
\text { tweens }\end{array}$ \\
\hline $\begin{array}{c}\text { Total } \\
\text { number }\end{array}$ & $\begin{array}{c}2128 \\
\text { commercials }\end{array}$ & $\begin{array}{c}1001 \\
\text { commercials }\end{array}$ & $\begin{array}{c}1127 \\
\text { commercials }\end{array}$ \\
\hline Percentage & $100 \%$ & $47 \%$ & $53 \%$ \\
\hline
\end{tabular}

Tab. 2. Structure of recorded commercials

The hypothesis according to which children and tweens are being casting advertising, not only for products and services that are designed for them is also validated, as actually the large majority of commercials featuring children or tweens refer to other types of products and services for which they are not the decision makers (78\%). (see table 3).

\begin{tabular}{|c|c|c|c|}
\hline & $\begin{array}{c}\text { Commercials } \\
\text { featuring } \\
\text { children or } \\
\text { tweens }\end{array}$ & $\begin{array}{c}\text { Addressed to } \\
\text { children and } \\
\text { tweens }\end{array}$ & $\begin{array}{c}\text { Not } \\
\text { addressed to } \\
\text { children and } \\
\text { tweens }\end{array}$ \\
\hline $\begin{array}{c}\text { Total } \\
\text { number }\end{array}$ & $\begin{array}{c}1001 \\
\text { commercials }\end{array}$ & $\begin{array}{c}222 \\
\text { commercials }\end{array}$ & $\begin{array}{c}778 \\
\text { commercials }\end{array}$ \\
\hline Percentage & $100 \%$ & $22 \%$ & $78 \%$ \\
\hline
\end{tabular}

Tab. 3. Structure of recorded commercials featuring children or tweens

Food products and especially confectionary, represent the area most inclined for including children or tweens in their advertising, regardless of the type of product: for adults only or also appropriate for children and tweens. Overall food items account for $74 \%$ of the commercials, while toys or other services designed for children and tweens are in minority. This situation reinforces the belief that children's and tweens' eating habits could be heavily influenced due to the behavioral displayed in commercials, especially for less healthy products such as sweets, and drinks with high content of sugar.

\begin{tabular}{|l|c|}
\hline Product categories & Percentage \\
\hline Confectionary & $45 \%$ \\
\hline Juice/ still drinks & $16 \%$ \\
\hline Breakfast cereals & $13 \%$ \\
\hline Games and toys & $10 \%$ \\
\hline $\begin{array}{l}\text { Media: Comic books/ books/ } \\
\text { movies }\end{array}$ & $9 \%$ \\
\hline Other & $\mathbf{7 \%}$ \\
\hline Total & $\mathbf{1 0 0 \%}$ \\
\hline
\end{tabular}

Tab. 4. Main product categories addressed to children and tweens featuring them in the advertising

In terms of children and tweens acting as triggers for parents by stirring the emotional side and determining them to consider purchasing the respective items, confectionary rank first, followed by laundry detergents and even insurance and banking services

\begin{tabular}{|l|c|}
\hline Product categories & Percentage \\
\hline Confectionary & $26 \%$ \\
\hline Laundry detergents & $16 \%$ \\
\hline Insurance and banking services & $15 \%$ \\
\hline Savory products & $13 \%$ \\
\hline Telecom services and handsets & $10 \%$ \\
\hline Automotive & $6 \%$ \\
\hline Pet food & $5 \%$ \\
\hline Personal care products & $3 \%$ \\
\hline Other & $6 \%$ \\
\hline Total & $100 \%$ \\
\hline
\end{tabular}

Tab. 5. Main product categories not addressed to children and tweens featuring them in the advertising

\section{CONCLUSION}

The current research proved that children and tweens prove to be highly cast in commercials across categories due to their influence over the family's purchases.

Besides mainly identifying and evaluating in more depth the triggers that make children and tweens one of the most desired symbols in TV advertising, further research should focus on identifying the ways in which childrens' and tweens' exposure to commercials featuring actors their own age is influencing their behavior and development as consumers on the long terms along with the reaction on the short term in terms of driving purchase for the respective product or service.

\section{REFERENCES}

Acuff, Dan. S (2000), What Kids buy and why, Simon \& Schuster, ISBN 0-684-83448-0

Carstea, M, (2010), Whom and How to research Online? Methodological consequences in using the new data collection techniques, PR Trends, 29-31 October 2010, Cluj Napoca

Edmond, S, (2006) Advertising to children: a changing media landscape, Young Consumers, Vol. 7 No. 4, pp. 8-12.

Kotz, K \& Story, M (1994), Food advertisings during children's Saturday morning television programming: Are they consistent with dietary recommendations? Journal of American Dietetic Associations, 94, 1296-1300

Valkenburga, P. M. , Cantor J. The development of a child into a consumer, Applied Developmental Psychology 22 (2001) 61-72)

***(2010) ARMA- Romanian Association for Audience Measurement, Accessed on: 2010-11-18 